\title{
Front Matter: Volume 10603
}

, "Front Matter: Volume 10603," Proc. SPIE 10603, Photonics, Devices, and Systems VII, 1060301 (1 December 2017); doi: 10.1117/12.2305964

SPIE. Event: Photonics Prague 2017, 2017, Prague, Czech Republic 


\title{
Photonics, Devices, and Systems VII
}

\author{
Karel Fiegel \\ Petr Páta \\ Editors
}

\section{8-30 August 2017 \\ Prague, Czech Republic}

Sponsored by

SPIE

Organized by

CSSF-Czech and Slovak Society for Photonics

Action M Agency (Czech Republic)

Cosponsored by

EOS-European Optical Society

Published by

SPIE 
The papers in this volume were part of the technical conference cited on the coverand title page. Papers were selected and subject to review by the editors and conference program committee. Some conference presentations may not be available for publication. Additional papers and presentation recordings may be available online in the SPIE Digital Library at SPIEDigitallibrary.org.

The papers reflect the work and thoughts of the authors and are published herein as submitted. The publisher is not responsible for the validity of the information or for any outcomes resulting from reliance thereon.

Please use the following format to cite material from these proceedings:

Author(s), "Title of Paper," in Photonics, Devices, and Systems VII, edited by Karel Fliegel, Petr Páta, Proceedings of SPIE Vol. 10603 (SPIE, Belling ham, WA, 2017) Seven-digit Article CID Number.

ISSN: 0277-786X

ISSN: 1996-756X (electronic)

ISBN: 9781510617025

ISBN: 9781510617032 (electronic)

Published by

SPIE

P.O. Box 10, Bellingham, Wa shington 98227-0010 USA

Telephone +1 3606763290 (Pacific Time)· Fax +1 3606471445

SPIE.org

Copyright ( 2017 , Society of Photo-Optic al Instrumentation Engineers.

Copying of material in this book for intemal or personal use, or for the intemal or personal use of specific clients, beyond the fair use provisions granted by the U.S. Copyright Law is authorized by SPIE subject to payment of copying fees. The Transactional Reporting Service base fee for this volume is $\$ 18.00$ per article (or portion thereof), which should be paid directly to the Copyright Clearance Center (CCC), 222 Rosewood Drive, Danvers, MA 01923. Payment may also be made electronically through CCC Online at copyright.com. Other copying for republication, resale, advertising or promotion, or any form of systematic or multiple reproduction of any material in this book is prohibited except with permission in writing from the publisher. The CCC fee code is 0277$786 \mathrm{X} / 17 / \$ 18.00$.

Printed in the United States of America.

Public ation of record for individual papers is online in the SPIE Digital Library.

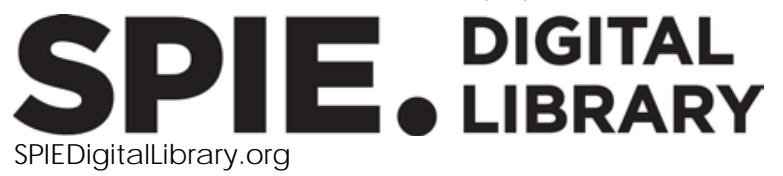

Paper Numbering: Proceedings of SPIE follow an e-First publication model. A unique citation identifier (CID) number is assigned to each article at the time of publication. Utilization of CIDs allows articles to be fully citable as soon as they are published online, and connects the same identifier to all online and print versions of the publication. SPIE uses a seven-digit CID article numbering system structured as follows:

- The first five digits correspond to the SPIE volume number.

- The last two digits indicate publication order within the volume using a Base 36 numbering system employing both numerals and letters. These two-number sets start with $00,01,02,03$, 04, 05, 06, 07, 08, 09, 0A, 0B ... 0Z, followed by 10-1Z, 20-2Z, etc. The CID Number appears on each page of the manuscript. 


\title{
Contents
}

\author{
vii Authors \\ ix Conference Committee \\ xiii Introduction \\ xv Tribute to Pavel Tománek
}

SESSION 1 LASER IN INDUSTRY

1060302 Advanced injection seeder for various applic ations: from UDARs to superc ontinuum sources [10603-24]

1060303 A practical model of thin disk regenerative amplifier based on analytical expression of ASE lifetime [10603-15]

1060304 A novel method for fabrication of size-controlled metallic nanoparticles by laser ablation [10603-41]

1060305 Cryogenic-cooled Tm:SBN tunable laser [10603-20]

1060306 Laser beam distribution system for the HiLASE Center [10603-2]

1060307 Q-switched Nd:YAG/V:YAG microchip 1338 nm laser for laser-induced breakdown spectrosc opy [10603-42]

1060308 High-efficient Nd:YAG microchip laser for optical surface sc anning [10603-36]

SESSION 2 MEIROLOGY AND SENSORS

1060309 Fibre optic gyroscope with single-mode fibre and loop-back phase shiftcompensation [10603-11]

10603 OA Camera-based micro interferometer for distance sensing [10603-35]

10603 OB Quality assessment of glass jewelry stones [10603-26]

10603 OC Large displacement and deformation measurement by frequency sweeping digital holography [10603-46]

\section{SESSON 3 UE SCIENCE AND BIOPHOTONICS}

10603 OD Assessing resolution in live cell structured illumination mic roscopy [10603-39] 
$10603 \mathrm{OE}$ Optical propagation analysis in photobioreactor measurements on cyanobacteria [10603-21]

\section{SESSION 4 SMMULATION OF PHOTONIC DEVICES}

10603 OF Thin films structural properties: results of the full-atomistic superc omputer simulation [10603-18]

10603 OG Evaluation of energy transfer coefficients in Tm-doped fibers for fiber lasers [10603-54]

$10603 \mathrm{OH}$ Design and optimization of the silver nanograting structure utilizing surface plasmonpolariton for inc rease of SERS sensor response [10603-6]

10603 ol Optical RRH working in an all-optical fronthaul network [10603-3]

\section{SESSION 5 DIRRACTIVE OPIICAL DEVICES}

10603 0] Fiber facet gratings for high power fiber lasers [10603-51]

10603 OK Theoretical model of a polanization diffrac tive elements for the light beams conversion holographic formation in PDLCs [10603-40]

\section{SESSON 6 WAVEGUIDE PHOTONICS}

10603 OL Monolithic thulium-doped fiberlaser[10603-47]

10603 OM Arsenic sulfide layers for dielectric reflection minors prepared from solution [10603-43]

10603 ON Design, fabrication and characterization of SOx/ SON/ SO2/Si structures for passive optical waveguides rea lization [10603-53]

1060300 Channel waveguides and phase diffraction gratings optically formed in photorefractive surface layers of lithium niobate [10603-16]

10603 OP Gain determination of optical active doped planar waveguides [10603-52]

$106030 \mathrm{Q}$ Measurement of attenuation coeffic ient of core and cladding modes in Bragg fiber [10603-44]

$10603 \mathrm{OR}$ Optical properties of $\mathrm{Na}_{2} \mathrm{O}-\mathrm{TO}_{2}-\mathrm{SO}_{2}$ glass films prepared by the sol-gel method [10603-48]

10603 OS The behavior of the geometrical parameters of optical beam of optical passive components under the long time themal load [10603-19]

10603 OT Formation of 2D bright spatial solitons in lithium niobate with photovoltaic response and incoherent background [10603-17] 


\section{SESSION 7 ORGANIC PHOTONIC MATERIALSAND DEVICES}

10603 OU Infrared wire-grid polarizer with sol-gel antireflection films on both sides [10603-5]

SESSION 8 NON-UNEAR MATERIALS, DEVICES, AND APPUCATIONS

10603 OV Thulium-doped optical fibers for fiber lasers [10603-8]

10603 OW Mode-locking peculiarities in an all-fiber erbium-doped ring ultrashort pulse laser with a highly-nonlinear resonator [10603-7]

10603 OX Analyses of electronic and optical properties of TIF-based azine derivatives [10603-10]

10603 OY All-solid-state, sync hronously pumped, ultrafast BaWO4 Raman laser with long and short Raman shifts generating at 1180, 1225, and 1323 nm [10603-45]

$106030 Z$ Generation of 120 ps, 1168 nm anti-Stokes pulses from the all-solid-state, self-modelocked, parametric Raman $\mathrm{CaCO}_{3}$ laser with intracavity pumping by 1338 nm Nd:YAG laser[10603-50]

1060310 Power requirements reducing of FG based all-optical switching [10603-25]

1060311 Analyses of resource resenation schemes for optical burst switc hing networks [10603-29]

1060312 Diode-pumped Cr-doped ZnMnSe and ZnMgSe lasers [10603-9]

SESSION 9 SOLAR CEUS, SOUD STATE UGHING AND LED, LD, OLED

1060313 Themal stability of gallium arsenide solar cells [10603-27]

1060314 Survey of on-road image projection with pixel light systems [10603-33]

1060315 Effic ient conceptual design for LED-based pixel light vehic le headlamps [10603-34]

1060316 Microscale localization and isolation of light emitting imperfections in monocrystalline silic on solar cells [10603-30]

1060317 Detection of mic rostruc tural defects in chalc opyrite Cu(In,Ga)Se2 solar cells by spectrallyfiltered electroluminescence [10603-4]

1060318 Modeling of photoluminescence in laser-based lighting systems [10603-32]

\section{SESSION 10 NANOPHOTONICSAND NANOOPICS}

1060319 Surface photonic crystal structures for LED emission modification [10603-49]

10603 1A Experimental vizualization of 2D photonic crystal equi-frequency contours [10603-38] 
10603 1B Reflectance analysis of porosity gradient in nanostructured silic on layers [10603-31]

SESSION 11 EDUCATION AND MULTIMEDIA IN PHOTONICS

10603 1C New generation of meteorology cameras [10603-55]

10603 1D Considerations of educ ation in the field of biophotonics in engineering: the experience of the subject fundamentals of biophotonics [10603-22] 


\section{Authors}

Numbers in the index correspond to the last two digits of the seven-digit citation identifier (CID) article numbering system used in Proceedings of SPIE. The first five digits reflect the volume number. Base 36 numbering is employed for the last two digits and indic ates the order of articles within the volume. Numbers start with 00,01,02,03,04,05, 06, 07, 08, 09, 0A, OB...0Z, followed by 10-1Z, 20-2Z, etc.

Arce-Diego, J. L., OE, 1D

Aubrecht, J an, OG, OL, OV

Ayadi, Awatef, OX

Ba ravets, Yauhen, 0J

Barton, Ivo, OM, OR

Batygov, Sergei H., 05

Bednarek, Lukas, 0S

Bezpaly, A., 00

Blažek, Martin, 1C

Cajzl, J a kub, OG, OV

Čech, M., 12

Chatzizyrli, Elisa vet, 18

Chen, Lyyuan, 03

Chlpík, J., ON

Choudhury, Kaushik, 04

Chovan, J., ON

Chyla, Michal, 03

Ctyroky, J in, 0J

Denisov, Lev K., OW

Divoký, Martin, 06

Doleček, Roman, OC

Doroshenko, Maxim E., 05, 12

Drzik, Milan, 1A

Dvoretskiy, Dmitriy A., OW

El-Ghayoury, Abdelkrim, OX

Endo, Akira, 03

Fa njul-Vélez, F., OE, 1D

Fialka, Jiř́, 09

Figura, D., ON

Fliegel, Ka rel, OD

Frank, Milan, 0Q, OY

Gajdos, A., 17

Gajdoš, Adam, 16

Gerasimenko, A. S., 12

Grigonev, F. V., OF

Grzes, Pawel, 02

Hajek, Lukas, OS

Havránek, Zdeněk, 09

Held, Marcel Philipp, 15

Heřmánek, Jan, 06

Honzátko, Pavel, 0G , 0J , OL, OV

Hruby, David, OS

Imamura, Kentaro, 1B

Ishihara, Yoshiro, OU

Ivleva, Lyudmila I., OY

J a nout, Petr, $1 \mathrm{C}$

J a ros, J a kub, oS

J elínek, Mic hal, 0Q, OY, OZ

J elínková, Helena, 05, 07, 08, 12
Jeřábek, Vítězslav, $\mathrm{OH}, \mathrm{OP}$

Jurečka, Stanislav, 1B

Kala chyova, Yevgeniya, $\mathrm{OH}$

Kamrádek, Michal, OG, OL, OV

Karasik, Valeriy E., OW

Kašík, Ivan, OG , OL, OQ , OV

Kaufman, Jan, 06

Kaván, František, $\mathrm{OC}$

Klíma, Miloš, OD

Knöchelmann, Marvin, 14

Koba ya shi, Hika ru, 1B

Komar, V. K., 12

Kracht, Dietmar, 18

Kubeček, Václav, OQ, OV, OY, OZ

Kudelin, Igor S., OW

Kumar, Ajai, 04

Kuzma, Anton, 19

Lachmayer, Roland, 14, 15, 18

La dányi, Libor, 10, 11

Latal, Jan, OS

Lédl, Vít, OC

Lettric hova, Iva na, 19

Ley, Peer-Phillip, 14

Lorenc, D., ON

Lyutakov, Oleksiy, $\mathrm{OH}$

Mackú, Robert, 16, 17

Macúchová, Ka rolina, 06

Makowska-J a nusik, Malgorzata, 0X

Mareš, David, $\mathrm{OH}$

Matějec, Vlastimil, $O M, O Q, O R$

Matoušek, Ondřej, OC

Matsumoto, Taketoshi, 1B

Mocek, Tomáš, 03, 06

Mraźek, Jan, OR, OV

Müllerová, J a mila, 10, 11

Muresan, Mihai-George, 06

Mydlova, Lucia, OX

Nagisetty, Siva Sankar, 03

Nasyrova, Maria, OB

Nedoma, J an, OS

Nejezchleb, Karel, 07, 08

Nekvindová, P., OP

Němec, Michal, 05, 12

Neumann, J örg, 18

Orekhov, llya O., OW

Ortlepp, Thomas, $0 A$

Osiko, Vyac heslav V., 05

Papashvili, Alexander G., 05

Papež, Nikola, 13 
Páta, Petr, 1C

Ped likova, J itka, OM

Perecar, Frantisek, OS

Peterka, Pavel, 0G, OL, OV

Pisarcik, Matej, 1A

Pnev, Alexey B., OW

Podrazký, Ondřej, OG, OL, OM, OQ, OV

Pospísili, J a kub, OD

Predoana, Luminita, OR

Proboštová, J ana, OG, OL

Psota, Pavel, OC

Pustozerov, A., 0T

Ranjan, Mukesh, 04

Řeháček, V., ON

Řeháková, Martina, 06

Říha, A., 12

Rizvi, Sa diq, 14

Růžička, Jan, 06

Sahra oui, Bouchta, OX

Sa zonkin, Sta nislav G., OW

Schaaf, Peter, 19

Schädel, Martin, OA

Scholtz, L'ubomír, 10, 11

Semkin, Artem O., OK

Senderakova, Dagmar, 1A

Shandarov, V., 0O, OT

Sharangovich, Sergey N., OK

Singh, R. K., 04

Skalský, Michal, 09

Ška rvada, Pavel, 16, 17

Škoda, Václav, 07, 08

Škrinia rová, J a rosla va, 19

Škvarenina, L'ubomír, 13, 16, 17

Šmejcký, Jiř́, OH, OP

Smetanin, Sergei, OY, OZ

Smrz, Martin, 03

Sobola, Dinara, 13

Solanská, Michaela, 10, 11

Srivastava, Atul, 04

Šulc, J an, 05, 07, 08

Sulimov, V. B., OF

Šušlik, L'uboš, 19

Švandrlík, Luděk, 06

Švejkar, Richard, 05

Tikhonravov, A. V., OF

Tinne, Nadine, 18

Todorov, Filip, 0J , OL

Tofel, Pavel, 13

Uherek, František, 0N, 19

Vanek, Martin, 0J

Vanis, Jan, 0J

Vasinek, Vladimir, OS

Verkhoturov, A., 00

Vítek, Stanislav, OB

Vyhlídal, D., 12

Wang, Dong, 19

Will, Matthias, OA

Yamada, Itsunari, OU

Zaharescu, Maria, $\mathrm{OR}$

Zakrzewski, Zbigniew, ol
Zhou, Huang, 03

Zverev, Petr G., OY 


\title{
Conference Committee
}

\author{
Conference Chair
}

Petr Páta, Czech Technic al University in Prague (C zech Republic)

Honorary Conference Co-chairs

Dagmar Senderáková, C omenius University in Bratisla va (Slova kia)

Miroslav Miller, Institute of Photonic s and Elec tronic s of the ASCR, v.v.i. (Czech Republic)

Conference Program Committee

José Luis Arce-Diego, Universida d de Cantabria (Spa in)

Pavel Cheben, National Research Counc il Canada (Canada)

James P. Connolly, The lle-de-France Photovoltaic Institute (France)

I. M. Dharmadasa, Sheffield Hallam University (United Kingdom)

Karel Fiegel, Czech Technical University in Prague (Czech Republic)

Ivan Glesk, University of Strathclyde (United Kingdom)

Helena Jelínková, Czech Technical University in Prague

(Czech Republic)

Ivan Kašik, Institute of Photonics a nd Electronics of the ASCR, v.v.i.

(C zech Republic)

Václav Kubeček, Czech Technical University in Prague

(C zech Republic)

MatanatA. Mehrabova, Azerbaijan National Aca demy of Sc iences

(Azerbaijan)

Roberto Morandotti, Institut National de la Recherche Scientifique

(Canada)

Petr Páta, Czech Technic al University in Prague (C zech Republic)

Pavel Peterka, Institute of Photonic s and Electronic s of the ASCR, v.v.i.

(C zech Republic)

Michael M. Pfeffer, Hoc hsc hule Ravensb urg-Weinga rten (Germany)

Dagmar Senderáková, Comenius University in Bratisla va (Slovakia)

Pavel Škarvada, Bmo University of Technology (Czech Republic)

Steve J. Smith, So uth Dakota School of Minesand Technology

(United States)

František Uherek, Intemational La ser Centre (Slova kia)

Vladimír Vašinek, VŠB-Technic a I University of Ostra va

(Czech Republic)

Tomasz R. Woliński, Warsa w University of Technology (Poland)

J avad Zarbakhsh, J ohannes Kepler Universität Linz (Austria) 
Pavel Zemánek, Institute of Sc ientific Instruments of the ASCR, v.v.i.

(Czech Republic)

Xing Zhu, Peking University (China)

Organizing Committee

Karel Fiegel, Czech Technic al University in Prague (Czech Republic)

Pavel Kašpar, Bmo University of Tec hnology (Czech Republic)

Petr Páta, Czech Technical University in Prague (Czech Republic)

František Rund, Czech Technical University in Prague

(Czech Republic)

Stanislav Vítek, Czech Technic al University in Prague (Czech Republic)

Milena Zeithamlová, Action M Agency (Czech Republic)

Session Chairs

1 La ser in Industry

Steve J. Smith, So uth Dakota School of Mines and Technology

(United States)

2 Metrology and Sensors

Ivan Kašík, Institute of Photonics a nd Electronics of the ASCR, v.v.i.

(Czech Republic)

3 Life Science and Biophotonics

Petr Páta, Czech Technic al University in Prague (C zech Republic)

4 Simulation of Photonic Devices

Dagmar Senderáková, Comenius University in Bratisla va (Slova kia)

5 Diffractive Optic al Devices

Dagmar Senderáková, Comenius University in Bra tisla va (Slova kia)

6 Waveguide Photonics

Dagmar Senderáková, Comenius University in Bratislava (Slova kia)

7 Organic Photonic Materialsand Devices

Pavel Peterka, Institute of Photonic s a nd Electronic s of the ASCR, v.v.i.

(Czech Republic)

$8 \quad$ Non-Linear Materials, Devic es, and Applications

Pavel Honzátko, Institute of Photonics and Electronic s of the ASCR,

v.v.i. (Czech Republic)

9 Solar Cells, Solid Sta te Lighting a nd LED, LD, OLED

Václav Kubeček, Czech Technic al University in Prague

(Czech Republic) 
10 Nanophotonicsand Nanooptics

František Uherek, Intemational La ser Centre (Slova kia)

11 Education and Multimedia in Photonics

Petr Páta, Czech Technic al University in Prague (C zech Republic)

Proc. of SPIE Vol. 10603 1060301-11

Downloaded From: https://www.spiedigitallibrary.org/conference-proceedings-of-spie on 26 Apr 2023 Terms of Use: https://www.spiedigitallibrary.org/terms-of-use 
Proc. of SPIE Vol. 10603 1060301-12 Downloaded From: https://www.spiedigitallibrary.org/conference-proceedings-of-spie on 26 Apr 2023
Terms of Use: https://www.spiedigitallibrary.org/terms-of-use 


\section{Introduction}

This volume contains a selection of 48 peer-reviewed papers from 87 contributions presented during the Photonics Prague 2017 conference, the eighth international conference in a series organized by the Czech and Slovak Society for Photonics (CSSF). This series started as a first national Photonics meeting in 1992, and after seven successful international conferences in Prague $(1995,1999,2002,2005,2008,2011,2014)$ it celebrates its $25^{\text {th }}$ year anniversary.

The conference is focused on the latest development in photonics with particular emphasis on devices and systems. This year the conference included 11 topical sessions covering various aspects of photonics.

1. Laser in Industry

2. Metrology and Sensors

3. Life Science and Biophotonics

4. Simulation of Photonic Devices

5. Diffractive Optical Devices

6. Waveguide Photonics

7. Organic Photonic Materials and Devices

8. Non-linear Materials, Devices, and Applications

9. Solar Cells, Solid State Lighting and LED, LD, OLED

10. Nanophotonics and Nanooptics

11. Education and Multimedia in Photonics

The conference attracted 92 active participants. The scientific program was comprised of 3 invited plenary talks, 34 oral presentations, and 50 poster presentations.

The Program Committee suggested three invited talks showing the emerging trends in photonics. The first one was presented by Kay Schuster from the Leibniz Institute of Photonic Technology (Germany) with the title "From Advanced Methods of Preform Fabrication to Specialty Coated Fibers - Material and Technology." The second talk was given by Pavel Zemánek from the Institute of Scientific Instruments (Czech Republic) with the title "Forces of Light: From Solar Sails to Nanoparticle Cooling." The third invited lecture entitled "Latest Advances in Biophotonics" was presented by Alžběta Marček Chorvátová from the International Laser Centre (Czech Republic).

We would like to thank all authors for their excellent contributions, which made for an outstanding conference, and members of the Program Committee for their effort in preparing the conference technical program, as well as for their detailed reviews of the submitted manuscripts. We would like to also thank the Organizing Committee for smooth local arrangements, the staff of SPIE for their support in preparing these Proceedings, and other people who made the conference happen.

We expect that the Photonics Prague conference series will continue, and we look forward to inviting scientists from all countries to attend the next conference in 2020. 
Proc. of SPIE Vol. 10603 1060301-14 Downloaded From: https://www.spiedigitallibrary.org/conference-proceedings-of-spie on 26 Apr 2023
Terms of Use: https://www.spiedigitallibrary.org/terms-of-use 


\section{Dedicated}

to the Memory of Pavel Tománek

The Photonics Prague 2017 conference and its proceedings are dedicated to the memory of Pavel Tománek, keen main organizer and long-term chair of Photonics Prague conference series. Our late esteemed colleague was sadly taken from us in May 2017.

Pavel Tománek, a renowned specialist in the field of photonics, optoelectronics, and nanotechnology, was connected for more than four decades as a researcher and professor of Applied Physics with the Faculty of Electrical Engineering and Communication of the Brno University of Technology, Brno, Czech Republic. Initially, he wanted to be a top athlete, but due to a ski accident, he changed his life path and eventually became a world-class expert in the mentioned scientific fields. He was an author of hundreds of research papers and textbooks and completed long-term internships in Algeria and France, where he also lectured. He co-organized many scientific conferences around the world, from Japan to the United States. He was enthusiastically dedicated to work and education of young colleagues, especially doctoral students. He was also very active in the Czech and Slovak Society for Photonics, acting as its president for the past three years.

We have lost a highly valued member of our research community, a colleague, and friend. May we continue to be inspired by his heritage in our future work.

Petr Páta 
Proc. of SPIE Vol. 10603 1060301-16 Downloaded From: https://www.spiedigitallibrary.org/conference-proceedings-of-spie on 26 Apr 2023
Terms of Use: https://www.spiedigitallibrary.org/terms-of-use 